\title{
Guanine Nucleotide-Binding Protein Subunit Alpha-11
}

National Cancer Institute

\section{Source}

National Cancer Institute. Guanine Nucleotide-Binding Protein Subunit Alpha-11. NCI

Thesaurus. Code C89719.

Guanine nucleotide-binding protein subunit alpha-11 (359 aa, $\sim 42 \mathrm{kDa}$ ) is encoded by the human GNA11 gene. This protein is involved in the activation of phospholipase C. 